The potency ratio of $\mathrm{Asp}^{1}-1 \mathrm{cc}^{5}$-angiolensin I relative to $\mathrm{Asp}^{1}-\mathrm{Ile} \mathrm{e}^{5}$-angiotensin II was 0.51 un a weight basis, or 0.63 on a molar basis, which accords with previously reported data (1).

Acknowledgments: We thank Mrs. Mituko Sokabe, and Mrs. Misuzu Arai for technical assistance.

\title{
REFERENCES
}

1) Page, I.H. and Bumpus, F.M.: Physiol. Rev. 41, 331 (1961); 2) Gross, F. and Turrian, H.: Polypeptides which Affect Smooth Muscles and Blood Vessels, Edited by Schachter, M., p. 137, Pergamon, New York (1960); 3) PaIVA, A.C.M. And PaIva, T.B.: Biochem. Pharmacol. 5, 187 (1960); 4) Paiva, T.B. ANd Paiva, A.C.A.: Br. J. Pharmacol. Chemother. 15, 557 (1960); 5) Bumpus, F.M., Khairalla, P.A., Arakawa, K., Pagf, I.H. and Smeby, R.R.: Biochim. hiophys. Acta 46, 38 (1961); 6) Guttmann, S.: Helv. chim. Acta 44, 721 (1961); 7) Helmer, O.M.: Am. J. Physiol. 207, 368 (1964); 8) Gould, A.B., Skeggs, L.T. and Kailn, J.R.: Lab. Invest. 15, 1802 (1966); 9) Boyd, G.W., Adamson, A.R., Fitz, A.E. ANd PEART, W.S.: Lancet 1 (7588), 213 (1969); 10) KreYe, V.A.W. AND Gross, F.: Am. J. Physiol. 220, 1294 (1971); 11) Okada, Y., Yoshimura, S., Shudo, K. and Sakakibra, S.: (in preparation); 12) NakaJima, T., Nakayama, T. and Sokabe, H.: Gen. comp. Endocrinol. 17, $458(1971)$; 13) Nakayama, T., Nakajima, T. And Sokabe, H.: Chem. Pharm. Bull. 20, 1579 (1972); 14) Finvey, D.J.: Statistical Method in Biological Assay, Charles Griffin, London, (1952)

\section{MORPHINE SPECIFIC SEIZURE INDUCED IN POLY-D-LYSINE PRETREATED MICE AND SOME EVIDENCE SUGGESTING THE PRESENCE OF A NOVEL SITE FOR THE MORPHINE EFFECT}

\author{
Masao KOIDA, Shigeru MURAOKA, Masakatsu TAKAHASHI \\ and Hiroshi KANETO \\ Department of Pharmacology, Faculty of Pharmaceutical Sciences, \\ Nagasaki University, Bunkyo-machi, Nagasaki, Japan
}

Accepted May 1, 1973

While studying the pharmacological properties of a morphine derivative covalently bound to the macromolecules, it was noticed that the mice, after being intracranially pretrealed with poly-D-lysine carrying the morphine derivative, responded to the s.c. injected dose of morphine in an unusual manner (1). A peculiar type of seizure, like the one inducible by strychnine, occurred and the animals died. The phenomenon was obscrved to similarly occur in mice pretreated with poly-D-lysine.

In the solution of physiological $\mathrm{pH}$, the polymer cxists as a strongly charged polycationic molecule and then, when such a molecule comes into contact with the ccll membrane, the easily conceivable consequence would be that the functions of the cell would more or less be inevitably modified $(2-7)$. From this viewpoint, the above described ob- 
servation may not be a novelty, however, the morphine induced scizure was never entirely masked by naloxone. Naloxone has been regarded as an all-purpose antagonist to a wide variety of morphine actions (8), therefore, the spccificity of the scizure-inducing effect of the opiate appeared worthy of further investigation.

Male nice of $d d$ strain weighing 19 to $21 \mathrm{~g}$ were used. Under light ether anesthesia, as described by Adler (9), the animal was intracranially given 25 / 25 of poly-D-lysine hydrobromide (purchased from Sigma, molectilar weight $75,000-150,000)$ in $25 / 4$ of saline. One hr later, saline, morhine hydrochloride ( $10 \mathrm{mg} / \mathrm{kg}$ ). sodium pentobarbital (40) $\mathrm{mg}$ ! $\mathrm{kg}$ ), chlorpromazine hydiochloride (2.2 mg/ $\mathrm{kg}$ ) or naloxone hydrochloride (5.0 or $10 \mathrm{mg} /$ $\mathrm{kg}$ ) was injected s.e. Here the dose of pentobarbital or chlorpromazine was calculated as the one corresponding to $10 \mathrm{mg} / \mathrm{kg}$ of morphine hydrochloride based on the ratio of the I.D to that of morphine. To test the protecting effect of naloxone, $5.0 \mathrm{mg} / \mathrm{kg}$ of

TABLE 1. Morphine-specific lethal effect in poly-D-lysine pretreated mice without naloxone

\begin{tabular}{|c|c|c|}
\hline Drugs & Dose, route & Death rate \\
\hline Saline & $0.2 \mathrm{ml}$, s.c. & $2: 25$ \\
\hline Morphine $\mathrm{HCl}$ & $10 \mathrm{mg} / \mathrm{kg}$, s.c. & $18 / 33$ \\
\hline $\begin{array}{l}\text { Naloxone } \mathrm{HCl} \\
\text { Morphine HCl }\end{array}$ & $\begin{array}{l}5 \mathrm{mg} \text { kg, i.p. } \times 2 \\
-10 \mathrm{mgkg} \text {, s.c. }\end{array}$ & $16: 27$ \\
\hline \multirow[t]{2}{*}{ Naloxone HCI } & $5 \mathrm{mgkg}$, s.c. & $0: 10$ \\
\hline & $10 \mathrm{mg} / \mathrm{kg}, \mathrm{s} . \mathrm{c}$. & 010 \\
\hline Chlorprom. $\mathrm{HCl}$ & $2.2 \mathrm{mg} \mathrm{kg}, \mathrm{s.c}$. & 0,8 \\
\hline Pentobarb. Na & $40 \mathrm{mg} \mathrm{kg}$, s.c. & $0: 16$ \\
\hline
\end{tabular}

All the animals used had been intracranially pretreated with $25 / \mathrm{g}$ of polyD-lysine hydrobromide I hr before.

the antagonist was given 1wice, i.p. 30 min before and 10 min after morphine injection.

Results are outlined in Table 1. In the group treated with poly-D-lysine and later saline, neither seizure nor death occurred for 3 hr after saline injection. During the next 2 days, two mice died. It was not clear whether the death was due 10 the action of the polymer or caused by nonspecific mechanisms such as bacterial infection or mechanical damage to brain tissue.

In the group on morphine, however, the majority of the animals exhibited tonic extension of limbs within a few hours and more than half died during convulsions. Usually, most deaths occurred within $3 \mathrm{hr}$ after the morphine dose while the animals which tolerated the seizure phase survived. In addition, it was confirmed that the morphine effect was not inhibited by naloxone. The time course in which the death occurred, was not affected by naloxone. On the other hand, an analgesic test (10) of some groups listed in Table 1 showed that pretreatment with poly-D-lysine had practically no influence on the analgesic effect of morphine and the naloxone inhibition of the analgesia appeared normally, indicating that the polymer did not modify the sensitivity of the site involved in the analgesic action. 
The other group treated with pentobarbital, chlorpromazine or naloxone did not show any sign of convulsion nor were there any deaths during a 2 day observation. It is considered, therefore, that the lethal effect would be specific to morphine.

These observations suggest that there is a site which specifically interacts with morphine to induce the convulsion and, when the sensitivity of the site to the drug is unusually increased by poly-D-lysine, the interaction proceeds in such a specific manner so as not to be infuenced by naloxone.

More detailed studies are now in progress regarding the mechanism of morphine action in relation to the phenomenon outlined herein.

\title{
REFERFNCFS
}

1) Koida, M. AND Kantor, H., Folia pharmacol. jap. 68, 265P (1972) (in Japancse); 2) Nevo, A., de Vries, A. And Katchalsky, A.: Biochim. Biophys, Acta 17,536(1955); 3) Katcilalsky, A., Danos, D., Nevo, A. And de Vries, A.: Biochim. Biophys. Acta 33, 120 (1959); 4) KorvGuth, S.E. and Stahmand, M.A.: Cancer Res. 21, 907 (1961); 5) Ryst:R, H. J.-P.: Science 159, 390 (1968); 6) Merrisil, J.N.: Fimop. J. Cancer 5, 427 (1969); 7) Padawer, J.: $J$. Cell. Biol. 47, 352 (1970): 8) MarTin, W.R.: Pharmacol. Rev. 19, 463 (1967); 9) Adler, T.K.: J. Plarmacol, exp. Ther. 140, 155 (1963); 10) Kandto, H., Survomura, K., Kamer, C. AND NaKanishi, H.: Folia pharmacol. jap. 66, 487 (1970) (in Japanese)

\section{THIAMINE ACCUMULATION INDUCED BY L-5-HYDROXY- TRYPTOPHAN IN RAT BRAIN}

\author{
Mieko KIMURA*, Yoshinori ITOKAWA** and Chikako TANAKA* \\ Department of Pharmacology* and Department of Hygicne,** \\ Faculty of Mericine, Kyoto University, Sakyo-kw, Kyoto, Janan
}

Accepted May 8, 1973

It has been reported by Iwata et al. that the catecholamine contents in the brain, heart and spleen are increased in thiamine deficient rats, while the blood catecholamine is decreased $(1,2)$. An increase in the brain serotonin contents and decrease in the liver, stomach and blood scrotonin contents have been found in the thiamine deficient rats by Kimura et al. and Itokawa et al. $(3,4)$. There is a concept that thiamine has a specific function in membrane transport in the nerve which is independent of its coenzyme role (5). Evidence for supporting this concept is the release of thiamine from the nerve preparation following electrical stimulation or application of ncuroactive drugs (6). In this paper, effects of L-5-hydroxytryptophan (L-5HTP) on the brain thiamine level were studied and compared to those of L-dihydroxyphenylalanine ( $L$-dopa).

Male Wistar rats, weighing 150-200 g, were maintained on a standard diet (CA-1, CLEA, Japan) with water ad libitum. Rats were administered i.p. L-5HTP (Kyowa Hakko) and L-dopa (Sankyo) in doses of 1, 10 and $100 \mathrm{mg} / \mathrm{kg}$. Drugs were suspended 